\title{
COXEN Score 26
}

National Cancer Institute

\section{Source}

National Cancer Institute. COXEN Score 26. NCI Thesaurus. Code C128223.

A score of 26 on the COXEN Sensitivity Scale. 